\title{
A qPCR Assay for the Detection of Phytophthora cinnamomi Including an mRNA Protocol Designed to Establish Propagule Viability in Environmental Samples
}

\author{
Manisha B. Kunadiya, ${ }^{1}$ William D. Dunstan, ${ }^{1}$ Diane White, ${ }^{1}$ Giles E. St. J. Hardy, ${ }^{1}$ Andrew H. Grigg, ${ }^{2}$ and Treena I. Burgess ${ }^{1, \dagger}$ \\ ${ }^{1}$ Centre for Phytophthora Science and Management, School of Veterinary and Life Sciences, Murdoch University, Murdoch, WA \\ 6150, Australia \\ ${ }^{2}$ Alcoa of Australia Ltd., Huntly Mine, Pinjarra, WA 6208, Australia
}

\begin{abstract}
Phytophthora cinnamomi causes root and collar rot in many plant species in natural ecosystems and horticulture. A species-specific primer and probe PCIN5 were designed based on a mitochondrial locus encoding subunit 2 of cytochrome c oxidase ( $\cos 2$ ). Eight PCR primers, including three forward and five reverse, were designed and tested in all possible combinations. Annealing temperatures were optimized for each primer pair set to maximize both specificity and sensitivity. Each set was tested against $P$. cinnamomi and two closely related clade 7 species, $P$. parvispora and $P$. niederhauseri. From these tests, five primer pairs were selected based on specificity and, with a species-specific $P$. cinnamomi probe, used to develop quantitative real-time PCR (qPCR) assays. The

clades (all except clade 3 ). The assay was able to detect as little as 150 ag of $P$. cinnamomi DNA and showed no cross-reaction with other Phytophthora species, except for $P$. parvispora, a very closely related species to $P$. cinnamomi, which showed late amplification at high DNA concentrations. The efficiency of the qPCR protocol was evaluated with environmental samples including roots and associated soil from plants artificially infected with $P$. cinnamomi. Different RNA isolation kits were tested and evaluated for their performance in the isolation of RNA from environmental samples, followed by cDNA synthesis, and qPCR assay. Finally, a protocol was recommended for determining the presence of $P$. cinnamomi in recalcitrant environmental samples.
\end{abstract} specificity of the two most sensitive qPCR assays was confirmed using the genomic DNA of 29 Phytophthora isolates, including 17 isolates of 11 species from clade 7, and representative species from nine other
Keywords: molecular diagnostics, species-specific primers, invasive pathogen, disease management
Phytophthora cinnamomi Rands is a soil-borne plant pathogen with a global distribution (Burgess et al. 2017), and is listed as one of the 100 worst invasive alien species in the global invasive species database (Lowe et al. 2000). P. cinnamomi has a wide host range and causes disease on over 5,000 host species of different genera of plants and horticultural crops (Erwin and Ribeiro 1996; Hardham and Blackman 2018). It causes dieback or death within Banksia woodland and heathlands in the southwest of Western Australia (Hardy et al. 2001; Shearer et al. 2007), where about $40 \%$ of the native plant species and half of the endangered species are susceptible (Shearer et al. 2004; Weste 2003). P. cinnamomi contributes to chestnut and oak decline in the Mediterranean region of Europe and the United States (Brasier 1996), and it also affects ornamental crops and nursery plants such as coniferous and broadleaf plants (Crandall et al. 1945; Ferguson and Jeffers 1999; Jung et al. 2015). Avocados are highly susceptible to P. cinnamomi; it was first detected in the early 1940s in California (Coffey 1987), and this disease threatens commercial avocado production globally (Engelbrecht and van den Berg 2013; Engelbrecht et al. 2017). For these reasons, early detection and identification of this pathogen are important steps for successful disease management procedures. Consequently, a robust and precise

${ }^{\dagger}$ Corresponding author: T. I. Burgess; tburgess@murdoch.edu.au

Funding: Financial support for the project comes from the Australian Research Council (ARC) Linkage project LP130100573 "Eradication of Phytophthora cinnamomi from infested haul roads and rehabilitated bauxite mine sites in the Eucalyptus marginata forest".

*The $\boldsymbol{e}$-Xtra logo stands for "electronic extra" and indicates that three supplementary tables are published online.

The author(s) declare no conflict of interest.

Accepted for publication 16 April 2019.

C 2019 The American Phytopathological Society detection method is essential for successful implementation of control strategies.

Many techniques have been developed for the detection of $P$. cinnamomi from infested soil, or from the infected whole plant or parts of plants, with varied success (Tsao and Ocana 1969; Zentmyer 1983). Various antibody-based diagnostic methods such as enzyme-linked immunosorbent assays (Comstock 1992; Kokoskova and Janse 2009), immunoblot (Nováková et al. 2006), immunofluorescent test (Malin et al. 1983), and lateral flow devices (Tomlinson et al. 2010) have been developed and widely used to identify plant pathogens. Antibody-based methods are fast, but specificity is often compromised owing to cross-reactivity with other pathogens (Franken et al. 1992).

Molecular genetic tools enable rapid identification of plant pathogens in various environmental samples including infected plant tissue. PCR is one of the most widely used methods for the detection of plant pathogens by targeting the specific sequences. Although it is sensitive and robust, there are some limitations. The assay specificity depends on primers used, its sensitivity makes it prone to false positives if care is not taken to avoid contamination, and it is unable to differentiate viable and nonviable cells in the reactions (Lau and Botella 2017). Quantitative real-time PCR (qPCR) is achieved through fluorescent detection, with the use of either a fluorescent probe or an intercalating dye. In qPCR assays, the target sequences are typically short (60 to 120 bases), allowing faster thermal cycling to be used compared with conventional PCR. Many PCR-based assays have been designed for $P$. cinnamomi (Kunadiya et al. 2017; O'Brien et al. 2009). However, most published primer sets have not been tested for specificity against closely related species, and most were not specific to $P$. cinnamomi (Kunadiya et al. 2017). There are several other types of molecular assay that have been used for species-specific detection of pathogens with varying success (Lau and Botella 2017), including loop-mediated isothermal amplification (Notomi et al. 2000) and helicase-dependent amplification (Vincent et al. 2004). We decided to pursue the qPCR methodology for its high sensitivity and specificity.

DNA can persist in soil and tissue after the death of the organism (Greaves and Wilson 1970; Nielsen et al. 2007; Paget et al. 1992; Recorbet et al. 1993; Romanowski et al. 1992, 1993; Widmer et al. 
1996). This poses a problem in DNA-based diagnostics, because it can lead to false positives, indicating the presence of a living pathogen even if it is dead (Scheu et al. 1998). RNA can be used as a viability marker because of its relatively rapid degradation in comparison with DNA (Chimento et al. 2012; Vettraino et al. 2010). RNA can be extracted from the suspect infected tissue and converted to cDNA, and then a standard specific qPCR assay can be used to detect the presence of the organism of interest (Alifano et al. 1994; Mendum et al. 1998; Sheridan et al. 1998).

Phytophthora dieback in Western Australia has been spread through infested soil adhering to machinery, through the use of infested gravel for roads, and also from infested nursery stock (Batini and Hopkins 1972; Davison 2018). Mining for bauxite by Alcoa of Australia in Western Australia, which involves the clearing and subsequent rehabilitation of approximately 600 ha of native jarrah forest each year, has a high potential to spread the pathogen into noninfested areas (Colquhoun and Hardy 2000). Moreover, the objective of rehabilitation is to restore a jarrah forest ecosystem, but approximately $20 \%$ of the jarrah forest is known to be affected by $P$. cinnamomi (Shearer and Tippett 1989; Wilson and Laidlaw 2001). Disease management during all facets of the mining and rehabilitation operations is critical, costing Alcoa an estimated US\$1.5 million a year (Colquhoun and Hardy 2000). Consequently, the development of accurate and reliable tools for the detection of $P$. cinnamomi from environmental samples is important for ongoing management and restoration of Alcoa's jarrah forest mine sites.

In this study, we present the development of a P. cinnamomi-specific probe-based qPCR assay based on the mitochondrial locus encoding subunit 2 of cytochrome c oxidase ( $\operatorname{cox} 2)$. We then tested and evaluated different commercial RNA extraction kits for the extraction of RNA from different environmental samples (infected plant tissue, soil, and mycelium). Following cDNA synthesis, the specific qPCR assay was then used to verify the presence of living propagules of $P$. cinnamomi from these samples.

\section{Materials and Methods}

DNA extraction, PCR amplification, and sequencing of the cox2 gene region. In Phytophthora, cox 2 is a highly variable protein coding region (Martin and Tooley 2003, 2004). However, cox 2 sequences for many newly described species, especially those described from Australia, are not available. Thus, to ensure a robust database for designing primers, the cox 2 region of 48 additional $P h y$ tophthora isolates from 46 Phytophthora species and undescribed taxa was sequenced, including additional isolates of $P$. cinnamomi and other clade 7 species.

All isolates were grown on half-strength potato dextrose agar (Difco, Becton Dickinson, Franklin Lakes, NJ) at $20^{\circ} \mathrm{C}$ for 2 weeks in the dark. Genomic DNA was extracted from mycelium using a ZR Fungal/Bacterial DNA MiniPrep kit (Zymo Research, Irvine, CA), following the manufacturer's instructions. Extracted DNA was stored in DNA elution buffer at $-20^{\circ} \mathrm{C}$.

For sequencing the $\operatorname{cox} 2$ gene region, PCR was conducted using forward primer Cox $2 \mathrm{~F}$ (Hudspeth et al. 2000) and reverse primer Cox2 RC4 (Choi et al. 2015). The amplification reaction was carried out on a thermal cycler (Bio-Rad; Applied Biosystems, Foster City, CA). In this, $1.5 \mu \mathrm{l}$ of genomic DNA extract was added to $23.5 \mu \mathrm{l}$ of a master mix containing $12.5 \mu \mathrm{l}$ of GoTaq Green Master Mix (Promega, Madison, WI), $10 \mu \mathrm{l}$ of PCR-grade water, and $0.5 \mu \mathrm{l}$ of each primer $(1 \mu \mathrm{M})$. PCR cycling conditions were as follows; initial denaturation temperature of $95^{\circ} \mathrm{C}$ for 4 min followed by 36 cycles at $95^{\circ} \mathrm{C}$ for $40 \mathrm{~s}$, annealing temperature of $55^{\circ} \mathrm{C}$ for $40 \mathrm{~s}$ and $72^{\circ} \mathrm{C}$ extension for $60 \mathrm{~s}$, followed by a final extension at $72^{\circ} \mathrm{C}$ for $5 \mathrm{~min}$. The PCR products were visualized by loading $5 \mu \mathrm{l}$ of the product on a $2 \%$ agarose gel containing SYBR Safe using Gel Doc System (Bio-Rad). Amplicons were quantified by comparison of band intensity against a 100-bp DNA ladder (Axygen Biosciences, Union City, CA).

PCR products were cleaned using Sephadex G-50 columns (Sigma Aldrich, Stockholm, Sweden) according to the manufacturer's instructions, and sequencing was performed as described by Sakalidis et al. (2011). PCR products were sequenced using the Big-Dye terminator cycle sequencing kit (PE Applied Biosystems) in both directions using the same primers that were used in the initial PCR amplification. The sequencing products were cleaned using Sephadex G-50 columns and were separated using an ABI3730 48 capillary sequencer (Applied Biosystems). Amplicon sequencing was performed at the Australian Genome Research Facility. All sequence data derived in this study have been deposited in GenBank (https:// www.ncbi.nlm.nih.gov/), and accession numbers are given in Supplementary Table $\mathrm{S} 1$. The amplicons were aligned using Geneious 7.1.4 (created by Biomatters; available from https://www.geneious.com/). Consensus sequences were generated through a BLAST search in GenBank in which all Phytophthora isolates were confirmed by sequence similarity to multiple matching sequences.

Primer design. Two hundred nineteen sequences of cox 2,173 from Phytophthora and 46 from other oomycetes, were aligned in Geneious. The region between 147 and 169 bp was targeted because between these positions the clade 7 Phytophthora species differed from all other Phytophthora clades and from each other. Primers were designed in Geneious using Primer3 version 2.3.4 software. This alignment was used to develop eight PCR primers (three forward and five reverse) and one probe for $P$. cinnamomi (Table 1). Primers were benchtop tested in Geneious against sequences of 121 other Phytophthora species and were predicted not to bind to any of them. Prime Time qPCR assay primers were ordered from Integrated DNA Technology (Coralville, IA) and were labeled with 6-FAM as the fluorescent dye.

Conventional PCR. The eight PCR primers were tested in all 15 possible combinations for amplification of $P$. cinnamomi using PCR conditions described above. From the 15 possible combinations, four PCR primer pair sets were selected based on band intensity of PCR product for P. cinnamomi: PCIN1 (PCIN147F/ PCIN249R), PCIN2 (PCIN146F/PCIN250R), PCIN3 (PCIN147F/ PCIN246R), and PCIN4 (PCIN150F/PCIN247R). The specificity of the four selected PCR primer sets was tested against $P$. cinna$m o m i$ and the closely related $P$. parvispora and $P$. niederhauser across a range of annealing temperatures from 55 to $64^{\circ} \mathrm{C}(55$, $58,59,60$, and $64^{\circ} \mathrm{C}$ ) (Table 2).

qPCR assay. qPCR was carried out on a Rotor-Gene 6000 (Qiagen, Hilden, Germany). Each $20-\mu l$ reaction contained $2 \mu l$ of template DNA (15 pg), $10 \mu \mathrm{l}$ of iTaq Universal Probes Supermix (Bio$\mathrm{Rad}$ ), $7.5 \mu \mathrm{l}$ of water (amplification grade; Promega), and $0.5 \mu \mathrm{l}$ of Prime Time qPCR assay (Integrated DNA Technology). The cycling conditions for all primer sets was $95^{\circ} \mathrm{C}$ for $3 \mathrm{~min}$, followed by $40 \mathrm{cy}-$ cles of $95^{\circ} \mathrm{C}$ for $10 \mathrm{~s}, 30 \mathrm{~s}$ at the annealing temperature of $55^{\circ} \mathrm{C}$, and $10 \mathrm{~s}$ extension at $72^{\circ} \mathrm{C}$. The negative controls contained nucleasefree water instead of DNA and were included in each run. Realtime PCR results were analyzed by threshold cycle $(\mathrm{Ct})$ value.

The DNA concentrations of extracts of mycelia from $P$. cinnamomi isolates MP94-48, P. parvispora isolate PAB13-29, and P. niederhauseri isolate DCE33 were determined with a Qubit 2.0 Fluorometer (Invitrogen; Life Technologies, Carlsbad, CA). A standard curve of $\mathrm{Ct}$ values was calculated using a $10^{-1}$ to $10^{-6}$ serial dilution of genomic DNA from P. cinnamomi MP94-48 (150 pg to 1.5 $\mathrm{fg}$ ). The threshold was automatically set with the Auto-Find Threshold function of the Rotor-Gene 6000 software; qPCR efficiency was calculated with the formula $\mathrm{E}=[10(-1 /$ slope $)-1] \times 100$, where $\mathrm{E}$ is the amplification efficiency and the slope is derived from the plot of the log of template concentration versus $\mathrm{Ct}$.

The specificity of the four primer qPCR assays (PCIN1, PCIN2, PCIN3, and PCIN4) was tested against $P$. cinnamomi and the closely related $P$. parvispora and $P$. niederhauseri at four different annealing temperatures: $55,59,60$, and $64^{\circ} \mathrm{C}$ (Table 3 ). The annealing temperature was optimized for the four primer sets using a serial dilution of $10^{-1}$ to $10^{-4}$ of $P$. cinnamomi (15 pg), P. niederhauseri (11 pg), and $P$. parvispora $(23 \mathrm{pg})$. Annealing temperatures of $55,59,60$, and $64^{\circ} \mathrm{C}$ were applied on qPCR for sensitivity analysis (Table 4), and cycling conditions were as mentioned above.

Primer specificity. The PCIN3 assay was selected as being the most specific and sensitive (Table 4). The PCIN5 assay was modified slightly from PCIN3 (Table 1). The PCIN3 and PCIN5 assays were 
further tested on genomic DNA of 29 Phytophthora isolates, including 17 isolates of 11 species from clade 7 , along with one species from each of the remaining except clade 3 (Table 5). The 11 species selected from clade 7 are interspersed within the clade 7 phylogeny and include $P$. parvispora, the species most closely related to $P$. cinnamomi (Cooke et al. 2000; Kunadiya et al. 2017). The cycling conditions for the PCIN3 and PCIN5 assays were an initial denaturation of $95^{\circ} \mathrm{C}$ for $3 \mathrm{~min}$, followed by 40 cycles of $95^{\circ} \mathrm{C}$ for $10 \mathrm{~s}$, primer set specific annealing temperature at $59^{\circ} \mathrm{C}$ for $30 \mathrm{~s}$, and $72^{\circ} \mathrm{C}$ extension for $10 \mathrm{~s}$.

Nested qPCR assay. After optimizing specificity and sensitivity of the assays, a nested approach was developed to improve sensitivity in detection from environmental samples. The nested protocol used Phytophthora-specific primers $\mathrm{Cox} 2 \mathrm{~F}$ and $\mathrm{Cox} 2 \mathrm{RC} 4$ in the first round in a conventional PCR, followed by either the PCIN3 or
PCIN5 qPCR assay in the second round using a template from the first round PCR. The tests were conducted on a 12 -fold serial dilution of genomic DNA of $P$. cinnamomi MP94-48 (1.5 ng initial concentration, dilution starting range; $150 \mathrm{pg}$ to $0.015 \mathrm{ag}$ ). The first-round PCR was carried out on a Bio-Rad thermal cycler. In all cases, the amplification reaction was $25 \mu$, with $2 \mu$ l of genomic DNA extract, $23 \mu \mathrm{l}$ of master mix containing $5 \mu \mathrm{l}$ of $5 \times$ colorless GoTaq Flexi Reaction buffer (Promega), $11.875 \mu$ l of water (amplification grade; Promega), $2.5 \mu \mathrm{l}$ of $25 \mathrm{mM} \mathrm{MgCl} 2$ (Promega), $1.5 \mu l$ of $100 \mathrm{nM}$ $\mathrm{dNTP}, 1 \mu \mathrm{l}$ of $10-\mathrm{ng} / \mathrm{ml}$ bovine serum albumin (Taylor et al. 2000), Taq polymerase ( 0.625 units), and $0.5 \mu$ l of each primer $(1 \mu \mathrm{M})$. An initial denaturation temperature was set at $95^{\circ} \mathrm{C}$ for 4 min; followed by three different cycle lengths $(25,30$, and $35 \mathrm{cy}$ cles) of denaturation at $95^{\circ} \mathrm{C}$ for $40 \mathrm{~s}$, annealing at $55^{\circ} \mathrm{C}$ for $40 \mathrm{~s}$, and extension at $72^{\circ} \mathrm{C}$ for $60 \mathrm{~s}$; with a final extension at $72^{\circ} \mathrm{C}$ for 5 min

Table 1. Primers and probe from the cytochrome c oxidase subunit 2 gene region used in this study

\begin{tabular}{lllc}
\hline Name & Direction & Sequence & Reference \\
\hline PCIN146F & Forward & TCCAGCAACTGTTGTGCATG & This study \\
PCIN147F & Forward & CCAGCAACTGTTGTGCATGG & This study \\
PCIN147F2 & Forward & CCAGCAACTGTTGTGCATGGA & This study \\
PCIN150F & Forward & GCAACTGTTGTGCATGGAGC & This study \\
PCIN246R & Reverse & ATAATAAAGCAAATGATGGT & This study \\
PCIN246R2 & Reverse & ATAATAAAGCAAATGATGGTATA & This study \\
PCIN247R & Reverse & TATAATAAAGCAAATGATGGT & This study \\
PCIN249R & Reverse & AATATAATAAAGCAAATGATGGT & This study \\
PCIN250R & Reverse & GAATATAATAAAGCAAATGATGGT & This study \\
PCIN259R & Reverse & TCATCCATTGAATATAATAAAGCA & This study \\
PCIN probe & & TGAAATTATTTGGACTTCTATACCTGC & This study \\
Cox2F & Forward & GGCAAATGGGTTTTCAAGATCC & Hudspeth et al. (2000) \\
Cox2RC4 & Reverse & TGATTWAYNCCACAAATTTCRCTACATTG & Choi et al. (2015) \\
\hline
\end{tabular}

${ }^{a}$ Double-quencher probes 5' 6-carboxyfluorescein, ZEN internal quencher, Iowa Black fluorescent quencher (5' 6-FAM/ZEN/3' IBFQ).

Table 2. Primer combinations tested for specificity toward Phytophthora cinnamomi at four different annealing temperatures $\left(55,58,59\right.$, and $\left.60^{\circ} \mathrm{C}\right)$ using conventional PCR ${ }^{\mathrm{a}}$

\begin{tabular}{|c|c|c|c|c|c|c|c|c|c|c|c|c|c|}
\hline \multirow[b]{2}{*}{ Primer pair combinations } & \multirow[b]{2}{*}{ Code $^{b}$} & \multicolumn{4}{|c|}{ P. cinnamomi } & \multicolumn{4}{|c|}{ P. niederhauseri } & \multicolumn{4}{|c|}{ P. parvispora } \\
\hline & & $55^{\circ}$ & $58^{\circ}$ & $59^{\circ}$ & $60^{\circ}$ & $55^{\circ}$ & $58^{\circ}$ & $59^{\circ}$ & $60^{\circ}$ & $55^{\circ}$ & $58^{\circ}$ & $59^{\circ}$ & $60^{\circ}$ \\
\hline PCIN147F + 249R & PCIN1 & + & + & + & + & + & + & - & - & + & + & + & + \\
\hline $\mathrm{PCIN} 146 \mathrm{~F}+250 \mathrm{R}$ & PCIN2 & + & + & + & + & + & - & - & - & + & + & + & + \\
\hline PCIN147F + 246R & PCIN3 & + & + & + & + & + & - & - & - & + & + & + & + \\
\hline PCIN150F + 247R & PCIN4 & + & + & + & + & + & - & - & - & + & + & + & + \\
\hline PCIN150F + 249R & & + & & & & + & & & & + & & & \\
\hline PCIN146F + 246R & & + & & & & + & & & & + & & & \\
\hline PCIN146F + 247R & & + & & & & + & & & & + & & & \\
\hline PCIN146F + 249R & & + & & & & + & & & & + & & & \\
\hline PCIN146F + 259R & & + & & & & + & & & & + & & & \\
\hline PCIN147F + 247R & & + & & & & + & & & & + & & & \\
\hline PCIN147F + 250R & & + & & & & + & & & & + & & & \\
\hline PCIN147F + 259R & & + & & & & + & & & & + & & & \\
\hline PCIN150F + 246R & & + & & & & + & & & & + & & & \\
\hline $\mathrm{PCIN} 150 \mathrm{~F}+250 \mathrm{R}$ & & + & & & & + & & & & + & & & \\
\hline PCIN150F + 259R & & + & & & & + & & & & + & & & \\
\hline
\end{tabular}

${ }^{\text {a }}$ Plus (+) indicates amplification. Data for annealing temperature of $64^{\circ} \mathrm{C}$ not shown in table because all results were negative.

$\mathrm{b}$ These four primer sets were converted to quantitative real-time PCR assays with the addition of a $P$. cinnamomi-specific probe (Table 1).

Table 3. Specificity of probe-based quantitative real-time PCR assays PCIN1, PCIN2, PCIN3, and PCIN4 toward Phytophthora cinnamomi at three different annealing temperatures $\left(55,59 \text {, and } 60^{\circ} \mathrm{C}\right)^{\mathrm{a}}$

\begin{tabular}{|c|c|c|c|c|c|c|c|c|c|c|c|c|c|}
\hline \multirow[b]{2}{*}{ Phytophthora species } & \multirow[b]{2}{*}{ DNA concentration (pg) } & \multicolumn{3}{|c|}{ PCIN1 } & \multicolumn{3}{|c|}{ PCIN2 } & \multicolumn{3}{|c|}{ PCIN3 } & \multicolumn{3}{|c|}{ PCIN4 } \\
\hline & & $55^{\circ}$ & $59^{\circ}$ & $60^{\circ}$ & $\overline{55^{\circ}}$ & $59^{\circ}$ & $60^{\circ}$ & $55^{\circ}$ & $59^{\circ}$ & $60^{\circ}$ & $55^{\circ}$ & $59^{\circ}$ & $60^{\circ}$ \\
\hline P. cinnamomi & 15 & + & + & + & + & + & - & + & + & + & + & + & + \\
\hline P. niederhauseri & 11 & + & + & - & + & + & - & - & - & - & + & - & - \\
\hline P. parvispora & 23 & + & + & + & + & + & - & + & + & + & + & + & + \\
\hline
\end{tabular}

a Plus (+) indicates amplification. Data for annealing temperature of $64^{\circ} \mathrm{C}$ not shown in table because all results were negative. 
and holding at $4{ }^{\circ} \mathrm{C}$. The second round of the PCR reaction used $2 \mu \mathrm{l}$ of amplification product from the first PCR round as in the template and was conducted on a Rotor-Gene 6000. Conditions for the second-round qPCR were as described above.

RNA extraction, cDNA synthesis, and reverse transcription PCR (RT-PCR). RNA was extracted from P. cinnamomi MP9448 freshly grown on half-strength potato dextrose agar (Difco) at $20^{\circ} \mathrm{C}$ for 2 weeks in the dark. Total RNA was extracted from $50 \mathrm{mg}$ wet weight of mycelium with the Power Plant RNA isolation kit (MoBio Laboratories, Carlsbad, CA), according to the manufacturer's instructions. Total RNA was further treated with the DNAfree DNase treatment kit (Ambion, Waltham, MA) to remove any genomic DNA contamination, according to the manufacturer's instructions. Total RNA concentration was determined with a Qubit 2.0 Fluorometer (Invitrogen). Extracted RNA was stored at $-80^{\circ} \mathrm{C}$ for further analysis.

The removal of genomic DNA during the RNA extraction was verified by using $2 \mu$ l of RNA extract in a nested PCR as previously described. To amplify cDNA from mRNA transcripts of $P$. cinnamomi, RT-PCR was conducted using qScript cDNA SuperMix (Quanta BioSciences, Beverly, MA) in 20- $\mu$ l reactions, using $2 \mu l$ of RNA as a template and $4 \mu \mathrm{l}$ of qScript cDNA SuperMix $(5 \times)$ and $14 \mu l$ of water (amplification grade, Promega). cDNA reactions were incubated at $25^{\circ} \mathrm{C}$ for $5 \mathrm{~min}$, followed by $30 \mathrm{~min}$ at $42^{\circ} \mathrm{C}$, and then inactivated at $85^{\circ} \mathrm{C}$ for $5 \mathrm{~min}$, using a PCR thermal cycler. Nested qPCR was then conducted using $2 \mu 1$ of cDNA as described above.

Extraction of RNA from environmental samples and detection of $P$. cinnamomi using a nested qPCR assay. $P$. cinnamomi isolate MP94-48 was used for all the experiments. Two experiments were conducted. Experiment 1 compared the performance of five commercially available kits in extracting total RNA from different environmental samples. Total RNA was isolated from (i) filter membranes used to capture chlamydospores and oospores, (ii) P. cinnamomiinfected stems of Banksia grandis, (iii) $P$. cinnamomi mRNA-spiked soil samples, and (iv) $P$. cinnamomi mycelium. The kits compared were (i) TRIzol Plus RNA Purification kit (Invitrogen), (ii) Qiagen RNeasy plant mini kit (Qiagen), (iii) MoBio Power Plant RNA isolation kit (MoBio), (iv) RNA Power Soil Total RNA Isolation Kit (MoBio), and (v) ZR soil/fecal RNA micro prep kits (Zymo Research, Irvine, CA). All kits were used following the manufacturers' recommended protocols.

For experiment 2, 5-month-old seedlings of $B$. grandis and $B$. attenuata were inoculated using millet inoculum of $P$. cinnamomi as described previously (El-Tarabily et al. 1997). After 4 to 5 weeks, roots were harvested and washed under running water and plated out on NARH Phytophthora-selective medium (Simamora et al. 2018).
After incubation, plates were examined microscopically for identification of $P$. cinnamomi. All fresh roots to be used for further RNA isolation experiments were stored at $-80^{\circ} \mathrm{C}$. The MoBio Power Plant RNA (MoBio) isolation kit was deemed the most reliable in

Table 5. Specificity of probe-based quantitative real-time PCR assays PCIN3 and PCIN5 at $59^{\circ} \mathrm{C}$

\begin{tabular}{lclcc}
\hline Isolate number $^{\mathbf{a}}$ & Clade & \multicolumn{1}{c}{ Species } & PCIN3 & PCIN5 \\
\hline PAB 12-23 & 1 & Phytophthora nicotianae & - & - \\
VHS13482 & 2 & P. elongata & - & - \\
WAC13201 & 2 & P. multivora & - & - \\
CBS 127950 & 4 & P. arenaria & - & - \\
CBS 587.95 & 5 & P. castaneae & - & - \\
VHS17175 & 6 & P. asparagi & + & - \\
HSA1658 & 6 & P. rosacearum & + & - \\
VHS13530 & 6 & P. thermophila & - & - \\
VHS16118 & 8 & P. pseudocryptogea & - & - \\
VHS16130 & 9 & P. constricta & - & - \\
CBS 291.29 & 10 & P. boehmeriae & - & - \\
TP 13-29 & 11 & P. versiformis & - & - \\
MP 94.48 & 7 & P. cinnamomi & + & + \\
TP 13-24 & 7 & P. cinnamomi & + & + \\
CBS 144.22 & 7 & P. cinnamomi & + & + \\
MUCC811 & 7 & P. cinnamomi & + & + \\
MUCC812 & 7 & P. cinnamomi & + & + \\
DCE25 & 7 & P. cinnamomi & + & + \\
PAB13-29 & 7 & P. niederhauseri & - & - \\
VHS17577 & 7 & P. niederhauseri & - & - \\
DCE33 & 7 & P. parvispora & + & + \\
CBS 125704 & 7 & P. sojae & - & - \\
W1846 & 7 & P. cambivora & - & - \\
P6870 & 7 & P. melonis & - & - \\
P3105 & 7 & P. cajani & - & - \\
P3109 & 7 & P. vignae & - & - \\
CBS 967.9 & 7 & P. rubi & - & - \\
CBS 133347 & 7 & P. asiatica & - & - \\
CBS 209.46 & 7 & P. fragariae & - \\
\hline Abbreviti & & + & - \\
\hline
\end{tabular}

${ }^{a}$ Abbreviations of isolate in culture collections (where known): CBS $=$ Centraalbureau voor Schimmelcultures, the Netherlands; VHS = Vegetation Health Service Collection, Department of Biodiversity, Conservation and Attractions (DBCA), Perth, Australia; PAB = personal collection of Paul Barber, held at Murdoch University (MU); $\mathrm{TP}=$ personal collection of Trudy Paap held at MU; P = isolate codes from World Phytophthora Collection, University of California, Riverside; WACC $=$ Western Australian Culture Collection, Department of Agriculture; MP = MU Phytophthora Culture Collection; MUCC $=$ MU Culture Collection; HSA $=$ Hart Simpson and Associates culture collection held at DBCA; and DCE $=$ Western Australia Department of Conservation and the Environment.

Table 4. Sensitivity of probe-based quantitative real-time PCR assays PCIN1, PCIN2, PCIN3, and PCIN4 toward Phytophthora cinnamomi at three different annealing temperatures $\left(55,59 \text {, and } 60^{\circ} \mathrm{C}\right)^{\mathrm{a}}$

\begin{tabular}{|c|c|c|c|c|c|c|c|c|c|c|c|c|c|c|}
\hline \multirow[b]{2}{*}{ Phytophthora isolates ${ }^{\mathrm{b}}$} & \multirow[b]{2}{*}{ DNA concentration } & \multicolumn{3}{|c|}{ PCIN1 } & \multicolumn{3}{|c|}{ PCIN2 } & \multicolumn{3}{|c|}{ PCIN3 } & \multicolumn{3}{|c|}{ PCIN4 } & \multirow{2}{*}{$\frac{\text { PCIN5 }}{59^{\circ}}$} \\
\hline & & $55^{\circ}$ & $59^{\circ}$ & $60^{\circ}$ & $55^{\circ}$ & $59^{\circ}$ & $60^{\circ}$ & $\overline{55^{\circ}}$ & $59^{\circ}$ & $60^{\circ}$ & $\overline{55^{\circ}}$ & $59^{\circ}$ & $60^{\circ}$ & \\
\hline P. cinnamomi & $1.5 \mathrm{pg}$ & + & + & + & + & + & - & + & + & + & + & + & + & + \\
\hline P. cinnamomi & $150.0 \mathrm{fg}$ & + & + & + & + & + & - & + & + & + & + & + & + & + \\
\hline P. cinnamomi & $15.0 \mathrm{fg}$ & + & + & + & + & + & - & + & + & + & + & + & + & + \\
\hline P. cinnamomi & $1.5 \mathrm{fg}$ & + & - & - & + & - & - & + & - & - & + & - & - & + \\
\hline P. cinnamomi & $150.0 \mathrm{ag}$ & - & - & - & - & - & - & - & - & - & - & - & - & - \\
\hline P. cinnamomi & $15.0 \mathrm{ag}$ & - & - & - & - & - & - & - & - & - & - & - & - & - \\
\hline P. niederhauseri & $1.1 \mathrm{pg}$ & + & - & - & + & + & - & - & - & - & + & - & - & - \\
\hline P. niederhauseri & $110.0 \mathrm{fg}$ & + & - & - & + & - & - & - & - & - & - & - & - & - \\
\hline P. niederhauseri & $11.0 \mathrm{fg}$ & - & - & - & + & - & - & - & - & - & - & - & - & - \\
\hline P. niederhauseri & $1.1 \mathrm{fg}$ & - & - & - & - & - & - & - & - & - & - & - & - & - \\
\hline P. parvispora & $2.3 \mathrm{pg}$ & + & + & + & + & + & - & + & + & + & + & + & + & + \\
\hline P. parvispora & $230.0 \mathrm{fg}$ & + & + & + & + & + & - & + & + & + & + & + & + & + \\
\hline P. parvispora & $23.0 \mathrm{fg}$ & + & + & + & + & + & - & + & - & - & + & - & - & - \\
\hline P. parvispora & $2.3 \mathrm{fg}$ & - & & - & - & - & - & - & - & - & - & - & - & - \\
\hline
\end{tabular}

${ }^{\text {a }}$ Plus (+) indicates amplification. Data for annealing temperature of $64^{\circ} \mathrm{C}$ not shown in table because all results were negative.

b P. cinnamomi isolate MP94-48, P. niederhauseri isolate PAB13-29, and P. parvispora isolate DCE33. 
experiment 1 and was compared with an additional three RNA extraction kits: (i) RapidPure RNA Plant Kit (MP Biomedicals, Santa Ana, CA), (ii) Direct-zol (Zymo Research), and (iii) RNAzol RT (Molecular Research Center, Cincinnati, OH). There were 10 replicate extractions each of the two infected Banksia roots per kit. All kits were used following the manufacturers' recommended protocols. Thereafter, an additional 30 infected root samples were tested using the RapidPure RNA Plant Kit.

Detection of $P$. cinnamomi in asymptomatic samples. One hundred and fifty-seven bulked environmental samples were collected from the surface of haul roads, roadside earthen bund walls, and sumps at Alcoa's Huntly mine site $\left(32^{\circ} 32^{\prime} \mathrm{S}, 116^{\circ} 14^{\prime} \mathrm{E}\right)$. Each sample was a composite of 10 separate sampling locations, located at 100-m intervals along haul roads and bund walls, or within each sump structure. The standard Centre for Phytophthora Science and Management baiting protocol was used: approximately $500 \mathrm{~g}$ of soil (and roots if present) were placed in a polycarbonate container (2.53 liters, Trenton International, St. Peters, NSW, Australia), and covered with water to 3/4 depth, and then bait leaves of Chamelaucium uncinatum, Hibbertia scandens, Scholtzia decussata, Pimelea sp., and Hedera canariensis were floated on the surface. The containers were incubated at 20 to $22^{\circ} \mathrm{C}$ for 7 to 10 days. As soon as lesions were observed, baits were removed and blotted dry on paper towels, cut into small pieces (1 to $3 \mathrm{~mm}$ ), and plated on NARH Phytophthoraselective medium. The plates were incubated at $25 \pm 2{ }^{\circ} \mathrm{C}$ in the dark for 3 to 5 days and checked for the growth of any Phytophthora spp.

After 10 days, all asymptomatic baits were removed, washed in a water, blotted dry, and cut into $2-\mathrm{mm}^{2}$ pieces and thoroughly mixed. A subsample was then taken and chopped into $0.5-\mathrm{mm}^{2}$ pieces for DNA extraction using the MoBio Power Plant DNA isolation kit following the manufacturer's protocol. The detection of $P$. cinnamomi was then undertaken using the nested qPCR protocol as described above.

\section{Results}

PCR primer specificity. Eight PCR primers, including three forward and five reverse in all possible combinations, amplified three Phytophthora species (the target species $P$. cinnamomi and nontarget $P$. parvispora and $P$. niederhauseri) at $55^{\circ} \mathrm{C}$ annealing temperature. From these results, four PCR primer pair sets, PCIN1 (PCIN147F/ PCIN249R), PCIN2 (PCIN146F/PCIN250R), PCIN3 (PCIN147F/ PCIN246R), and PCIN4 (PCIN150F/PCIN247R), each producing a product of approximately $100 \mathrm{bp}$, were selected based upon the relative band intensity for $P$. cinnamomi in comparison with the nontarget species $P$. parvispora and $P$. niederhauseri. None of the primer sets amplify $P$. cinnamomi, $P$. parvispora, and $P$. niederhauseri above $60^{\circ} \mathrm{C}$. These four primer sets successfully amplified $P$. cinnamomi at $55,58,59$, and $60^{\circ} \mathrm{C}$ (Table 2). The four primer sets all amplified $P$. niederhauseri at $55^{\circ} \mathrm{C}$, and PCIN1 amplified $P$. niederhauseri at $58^{\circ} \mathrm{C}$ (Table 2). All four primer sets amplified P. parvispora at 55, 58,59 , and $60^{\circ} \mathrm{C}$ (Table 2).

qPCR assay. Four qPCR assays were developed by the addition of the $P$. cinnamomi-specific probe (Table 3). Assays PCIN1, PCIN3, and PCIN4 amplified $P$. cinnamomi and $P$. parvispora at annealing temperatures of 55,59 , and $60^{\circ} \mathrm{C}$ (Table 3). PCIN2 was negative for $P$. cinnamomi, $P$. niederhauseri, and $P$. parvispora above $59^{\circ} \mathrm{C}$. All assays could detect $P$. cinnamomi at $1.5 \mathrm{fg}$ and $P$. parvispora at $23 \mathrm{fg}$ with an annealing temperature of $55^{\circ} \mathrm{C}$. PCIN3 and PCIN4 detection thresholds were one order of magnitude less at 59 and $60^{\circ} \mathrm{C}$ for P. cinnamomi and P. parvispora (Table 4). PCIN3 did not amplify $P$. niederhauseri, whereas other assays did so at various concentrations: PCIN1 amplified $P$. niederhauseri at $55^{\circ} \mathrm{C}$ at $110 \mathrm{fg}, \mathrm{PCIN} 2$ amplified it at $55^{\circ} \mathrm{C}$ at $11 \mathrm{fg}$ and at $59^{\circ} \mathrm{C}$ at $1.1 \mathrm{pg}$, and PCIN4 amplified it at $1.1 \mathrm{pg}$ at $55^{\circ} \mathrm{C}$ (Tables 3 and 4).

$P$. parvispora is closely related to $P$. cinnamomi, and although the benchtop analysis predicted the primers and probe would not bind, when tested they did. Of the assays, PCIN3 was considered the most effective because it did not amplify $P$. niederhauseri, a species commonly found in forests or urban and peri-urban environments in Western Australia. PCIN5 was a new assay modified from PCIN3 by an adjustment to the primer sequence (Table 1). PCIN5 was one level of magnitude more sensitive than PCIN3 in the detection of $P$. cinnamomi at $59^{\circ} \mathrm{C}(1.5 \mathrm{fg}$ compared with $15 \mathrm{fg}$ ) (Table 4).

The specificity of PCIN3 and PCIN5 assays was further tested on genomic DNA of 29 Phytophthora isolates, including 17 isolates representing 11 species from clade 7 and a representative species from nine other clades (Table 5). The PCIN3 primer set amplified all six isolates of $P$. cinnamomi, and three other species; $P$. parvispora, $P$. asparagi, and $P$. rosacearum. The PCIN5 assay showed no crossreaction with other Phytophthora species, except for $P$. parvispora, which showed late amplification at relatively high DNA concentrations (23 ng) at an annealing temperature of $59^{\circ} \mathrm{C}$ (Table 5).

Nested qPCR assay. To determine the sensitivity of the PCIN3 and PCIN5 primer assays, qPCR and nested qPCR were compared. Both assays were performed using a serial dilution of $P$. cinnamomi DNA ranging from $150 \mathrm{pg}$ to $150 \mathrm{ag}$. The lowest concentration detected using qPCR with an annealing temperature of $59^{\circ} \mathrm{C}$ for PCIN3 was $15 \mathrm{fg}$ and PCIN5 was $1.5 \mathrm{fg}$ (Table 4). The nested qPCR approach, using Cox $2 \mathrm{~F}$ and $\mathrm{Cox} 2 \mathrm{RC} 4$ in the first round, increased the sensitivity of the assay by at least 1,000-fold, down to $150 \mathrm{ag}$ for both PCIN3 and PCIN5 (Table 6).

Comparison of RNA extraction kits. The success of an RNAbased assay depends on the performance of kits and the quality, purity, and integrity of the total RNA as determined after the RT-PCR. In the first experiment, the yield of total RNA was higher with the MoBio Power Plant kit than with the other four kits (Fig. 1). The kit also demonstrated the best performance on the different samples tested; filter membrane, mycelium, colonized infected plugs, and spiked soil samples (Fig. 1). The ZR soil/fecal RNA micro prep kit

Table 6. Sensitivity of probe-based quantitative real-time PCR assays PCIN3 and PCIN5 toward Phytophthora cinnamomi using a nested approach in which generic Phytophthora primers Cox $2 \mathrm{~F}$ and Cox $2 \mathrm{RC} 4$ were used in first PCR using three different cycling conditions $(25,30 \text {, and } 35 \text { cycles })^{\mathrm{a}}$

\begin{tabular}{|c|c|c|c|c|c|c|c|}
\hline \multirow[b]{2}{*}{ Dilution } & \multirow[b]{2}{*}{ DNA concentration } & \multicolumn{3}{|c|}{$\begin{array}{c}\text { Ct value at } 59^{\circ} \mathrm{C} \\
\text { PCIN3 } \\
\end{array}$} & \multicolumn{3}{|c|}{$\begin{array}{c}\mathrm{Ct} \text { value at } 59^{\circ} \mathrm{C} \\
\text { PCIN5 } \\
\end{array}$} \\
\hline & & 25 & 30 & 35 & 25 & 30 & 35 \\
\hline $10^{-1}$ & $150.0 \mathrm{pg}$ & 9.0 & 8.8 & 8.2 & 9.7 & 10.6 & 8.9 \\
\hline $10^{-2}$ & $15.0 \mathrm{pg}$ & 10.1 & 8.5 & 8.1 & 10.5 & 10.1 & 8.5 \\
\hline $10^{-3}$ & $1.5 \mathrm{pg}$ & 12.3 & 8.6 & 8.1 & 12.6 & 9.4 & 8.4 \\
\hline $10^{-4}$ & $150.0 \mathrm{fg}$ & 16.9 & 9.7 & 8.5 & 16.9 & 9.9 & 8.4 \\
\hline $10^{-5}$ & $15.0 \mathrm{fg}$ & 21.9 & 14.0 & 10.5 & 22.2 & 14.1 & 10.2 \\
\hline $10^{-6}$ & $1.5 \mathrm{fg}$ & 24.4 & 15.4 & 13.8 & 24.5 & 15.4 & 13.1 \\
\hline $10^{-7}$ & $150.0 \mathrm{ag}$ & 26.2 & 21.9 & 16.2 & 25.9 & 22.0 & 15.3 \\
\hline $10^{-8}$ & $15.0 \mathrm{ag}$ & - & - & - & - & - & - \\
\hline $\mathrm{Neg}$ & Negative & - & - & - & - & - & - \\
\hline
\end{tabular}

${ }^{\mathrm{a}} \mathrm{Ct}=$ cycle threshold.

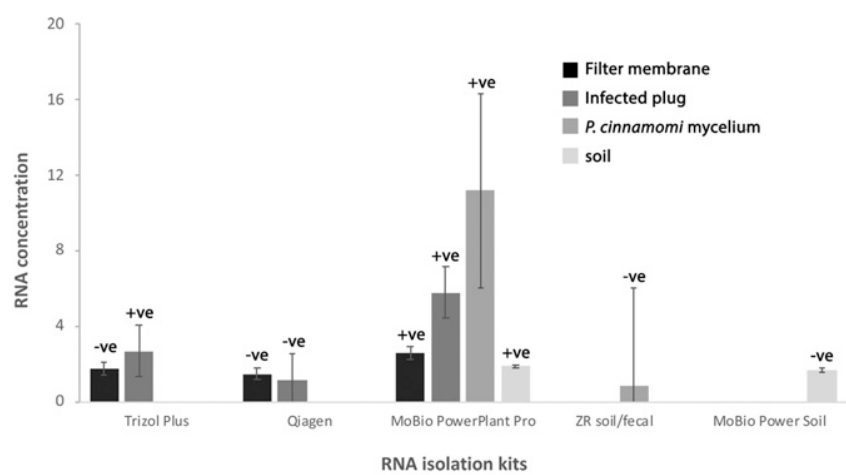

Fig. 1. The yield of total RNA (ng) isolated with five different RNA isolation kits. Details of the kits are provided in the Materials and Methods section. A positive result (+ve) indicated that Phytophthora cinnamomi was detected in a nested quantitative real-time PCR (qPCR), and negative (-ve) indicated that $P$. cinnamomi was not detected in a nested qPCR. 
gave a low recovery of RNA and contained high levels of genomic DNA contamination (Fig. 1). RNA extracted using the MoBio Power Plant RNA isolation kit and TRIzol Plus RNA Purification kit were amplified by qPCR and showed high $\mathrm{Ct}$ values, indicative of the presence of $P$. cinnamomi in environmental samples, whereas other kits produced no amplification, and their results were considered negative.

In a second experiment, initial trial work was performed on 10 $P$. cinnamomi-infected $B$. grandis and $B$. attenuata root samples and four different kits. The yield of total RNA isolated with the RapidPure RNA Plant Kit (MP Biomedicals) was higher and consistently positive in RT-PCR assay than with the other three kits. Results for the MoBio Power Plant RNA isolation kit, Direct-zol RNA kit, and RNAzol RT RNA isolation kit were inconsistent. To verify this result, the RapidPure RNA Plant kit was further tested on 30 infected root samples, and it was consistent with a high yield of total RNA (Supplementary Table S2).

Detection of $\boldsymbol{P}$. cinnamomi in asymptomatic baits. Of the 157 samples, only one was positive for $P$. cinnamomi using the traditional baiting methodology (Supplementary Table S3). A further 17 samples were positive when DNA was extracted from the asymptomatic baits and subjected to $P$. cinnamomi-specific nested qPCR. All 18 positive samples were collected from sump locations; none were collected from road surfaces or bund walls. The P. cinnamomi DNA concentration was much lower $(1.27 \pm 0.39 \mathrm{pg})$ from the asymptomatic sample compared with the positive control (the sample in which lesions were visible on the baits and P. cinnamomi was isolated), which contained $540 \mathrm{ng}$.

\section{Discussion}

The present study describes the development of a $P$. cinnamomi species-specific qPCR assay, with optimum specificity and sensitivity. There are other assays available (Kunadiya et al. 2017), but either the primers are not specific to $P$. cinnamomi or they are not designed on protein-coding gene regions and thus are inappropriate for an RNA-based assay. The nested qPCR assay described here can detect $P$. cinnamomi DNA from environmental samples at a concentration calculated to be equivalent to $0.1 \%$ of the DNA in a single cell of $P$. cinnamomi. The designed primers can be used in RT-qPCR assays following RNA extraction. We have shown this through experiments on different environmental samples from which RNA was successfully isolated. However, the effectiveness of such an assay is currently limited (because sample sizes are relatively small, $50 \mathrm{mg}$ per plant sample or $250 \mathrm{mg}$ of soil sample) and the kits and chemicals for the assay are expensive. This contrast is seen with baiting of soil/rhizosphere samples of $500 \mathrm{~g}$ or greater.

In a previous study, we compared specificity and sensitivity of several published $P$. cinnamomi assays (Kunadiya et al. 2017). Of those that proved to be specific to $P$. cinnamomi, Ycin3F/Ycin4R (Schena et al. 2008) could detect $150 \mathrm{fg}$ of $P$. cinnamomi DNA in conventional PCR and $15 \mathrm{fg}$ in a nested PCR. Internal transcribed spacer primers PciF2/PciR2 (Langrell et al. 2011) could detect as litthe as 15 ag of $P$. cinnamomi DNA in a nested PCR, and a qPCR assay using primers ATP9-F/NAD9-nfo-R (Miles et al. 2014) could detect $150 \mathrm{fg}$ of $P$. cinnamomi DNA (Kunadiya et al. 2017). The primers described in the current study can detect 150 ag of $P$. cinnamomi DNA and unlike the primers above is based on a protein-coding region and thus can be used for RNA assays.

The assay developed in this study produced a late amplification of $P$. parvispora, the species most closely related to $P$. cinnamomi. To eliminate this amplification, we can raise the annealing temperature to over $60^{\circ} \mathrm{C}$. This, however, greatly reduces the sensitivity of the assay. P. parvispora is rarely encountered in the southwest of Western Australia, and for this reason the assay with an annealing temperature of $59^{\circ} \mathrm{C}$ is suitable for the detections of $P$. cinnamomi in this environment. We believe there are many systems in which $P$. parvispora has not been detected, or is very rare, and thus the assay has high applicability for the robust detection of $P$. cinnamomi DNA.

DNA-based methods can detect an organism even if it is not living, which has the disadvantage of giving false positive results (Chimento et al. 2012; Josephson et al. 1993; Nocker and Camper 2006). The detection of mRNA from the sample indicates either that cell is alive or has died recently (Sheridan et al. 1998). The assay developed here can be used in conjunction with RNA extraction and cDNA synthesis, to provide definitive proof of the presence of living $P$. cinnamomi. This is theoretically far superior to a DNA-based assay. However, we encountered several obstacles that prevent the rollout of a cheap and reliable RNA-based assay. First, the quality of RNA is critical for accurate mRNA quantification. mRNA is a labile molecule and rapidly degraded after cell death. Currently, the major drawback to an mRNA-based assay is difficulties with preparing and handling the samples, in particular obtaining RNA that is free from DNA contamination. Therefore, for every RNA extraction, we first conducted a nested qPCR application to check for any DNA contamination, and if DNA contamination was absent, then cDNA was synthesized from DNase-treated RNA. This is a time-consuming and expensive process. Additionally, the commercially available kits varied greatly in their efficiency of extraction and consistency of results. In this study, we evaluated eight commonly used commercial RNA isolation kits for the best performance by comparing RNA quality and yield for different environmental samples. We selected the best RNA isolation protocol and established an RNA assay that work well for cultured mycelium and environmental samples (if the viability of the $P$. cinnamomi was established before by direct plating). However, for samples known to be infected with $P$. cinnamomi, such as small pieces of infected root that have been allowed to dry naturally, we needed to first stimulate the growth of $P$. cinnamomi by incubation in water, in order to extract sufficient RNA to get a positive result (unpublished data). At the same time, these samples could be grown out on Phytophthora-selective medium, a much cheaper option than RT-qPCR. It appears that if $P$. cinnamomi is present in resting structures, it is quiescent and not producing enough detectable RNA (Rittershaus et al. 2013). Thus, at this point in time, it is still preferable to use traditional isolation methods to establish the presence of living P. cinnamomi in environmental samples.

The DNA-intercalating dye propidium monoazide (PMA) is a photoreactive DNA-binding dye that enables distinguishing living cells from dead cells. It is used to detect viable cells by qPCR and is referred to as viability PCR (v-PCR) (Heise et al. 2016). However, there is evidence that v-PCR using DNA-intercalating dyes has practical and theoretical limitations, especially when applied to environmental samples (Pisz et al. 2007; Varma et al. 2009; Wagner et al. 2008). The greatest concern with PMA is the generation of falsepositive signals owing to incomplete signal suppression. The use of v-PCR to differentiate between viable and nonviable organisms appears to be matrix dependent (Fittipaldi et al. 2012), which limits its use as a routine assay.

To move forward with a best practice diagnostic protocol for $P$. cinnamomi from environmental samples, we have developed a hybrid methodology for the detection of $P$. cinnamomi in recalcitrant environmental samples in which traditional baiting is coupled with the molecular detection of $P$. cinnamomi DNA from asymptomatic baits. The method is not dissimilar to that proposed by Sena et al. (2018), who developed a rapid assay in which DNA was extracted from bait discs and then subjected to $P$. cinnamomi-specific PCR assay based on the Ypt gene region. This bait-PCR method is superior to either baiting or direct molecular detection alone for the following reasons: First, when only using traditional baiting techniques, leaves can become infected but remain asymptomatic, which leads to false negatives. Second, when using only species-specific PCR from environmental samples, false positives as well as amplification can be obtained even if the pathogen is dead. Because the bait leaves are living tissue, it is assumed in the bait-PCR method that a living propagule (zoospore) of $P$. cinnamomi would need to have been present to infect the baits. We analyzed 157 samples from fallow haul roads, bunds, and sumps and detected $P$. cinnamomi using the qPCR assay in low concentrations from asymptomatic leaves in 18 samples, whereas $P$. cinnamomi was only isolated based on production of lesions on baits from a single sample. These samples were all from sumps that collect haul road runoff. We recommend this protocol 
for the detection of $P$. cinnamomi from agriculture, forestry, and natural ecosystems, especially when the pathogen is suspected to be present but cannot be detected by traditional methods.

\section{Acknowledgments}

We thank Emeritus Professor Jen McComb for reviewing the manuscript.

\section{Literature Cited}

Alifano, P., Bruni, C. B., and Carlomagno, M. S. 1994. Control of mRNA processing and decay in prokaryotes. Genetica 94:157-172.

Batini, F., and Hopkins, E. 1972. Phytophthora cinnamomi Rands-A root pathogen of the jarrah forest. Aust. For. 36:57-68.

Brasier, C. M. 1996. Phytophthora cinnamomi and oak decline in southern Europe: Environmental constraints including climate change. Ann. Sci. For. 53: $347-358$.

Burgess, T. I., Scott, J. K., McDougall, K. L., Stukely, M. J. C., Crane, C., Dunstan, W. A., Brigg, F., Andjic, V., White, D., Rudman, T., Arentz, F. A., Ota, N., and Hardy, G. E. S. 2017. Current and projected global distribution of Phytophthora cinnamomi, one of the world's worst plant pathogens. Global Change Biol. 23: 1661-1674.

Chimento, A., Cacciola, S. O., and Garbelotto, M. 2012. Detection of mRNA by reverse-transcription PCR as an indicator of viability in Phytophthora ramorum. For. Pathol. 42:14-21.

Choi, Y. J., Beakes, G., Glockling, S., Kruse, J., Nam, B., Nigrelli, L., Ploch, S., Shin, H.-D., Shivas, R. G., Telle, S., Voglmayr, H., and Thines, M. 2015. Towards a universal barcode of oomycetes-A comparison of the coxl and cox2 loci. Mol. Ecol. Resour. 15:1275-1288.

Coffey, M. D. 1987. Phytophthora root rot of avocado. Plant Dis. 71:1046-1052.

Colquhoun, I., and Hardy, G. E. St. J. 2000. Managing the risks of Phytophthora root and collar rot during bauxite mining in the Eucalyptus marginata (jarrah) forest of Western Australia. Plant Dis. 84:116-127.

Comstock, J. C. 1992. Detection of the sugarcane leaf scald pathogen, Xanthomonas albilineans, using tissue blot immunoassay, ELISA, and isolation techniques. Plant Dis. 76:1033-1035.

Cooke, D., Drenth, A., Duncan, J., Wagels, G., and Brasier, C. 2000. A molecular phylogeny of Phytophthora and related oomycetes. Fungal Genet. Biol. 30: 17-32.

Crandall, B. S., Gravatt, G., and Ryan, M. M. 1945. Root disease of Castanea species and some coniferous and broadleaf nursery stocks, caused by Phytophthora cinnamomi. Phytopathology 35:162-180.

Davison, E. 2018. Relative importance of site, weather and Phytophthora cinnamomi in the decline and death of Eucalyptus marginata-Jarrah dieback investigations in the 1970s to 1990s. Aust. J. Plant Pathol. 47:245-257.

El-Tarabily, K. A., Hardy, G. E. St. J., Sivasithamparam, K., Hussein, A. M., and Kurtböke, D. I. 1997. The potential for the biological control of cavity-spot disease of carrots, caused by Pythium coloratum, by streptomycete and nonstreptomycete actinomycetes. New Phytol. 137:495-507.

Engelbrecht, J., Duong, T. A., and Berg, N. 2017. New microsatellite markers for population studies of Phytophthora cinnamomi, an important global pathogen. Sci. Rep. 7:17631.

Engelbrecht, J., and van den Berg, N. 2013. Expression of defence-related genes against Phytophthora cinnamomi in five avocado rootstocks. S. Afr. J. Sci. 109:1-8.

Erwin, D. C., and Ribeiro, O. K. 1996. Phytophthora Diseases Worldwide. American Phytopathological Society, St. Paul, MN.

Ferguson, A., and Jeffers, S. 1999. Detecting multiple species of Phytophthora in container mixes from ornamental crop nurseries. Plant Dis. 83:1129-1136.

Fittipaldi, M., Nocker, A., and Codony, F. 2012. Progress in understanding preferential detection of live cells using viability dyes in combination with DNA amplification. J. Microbiol. Methods 91:276-289.

Franken, A., Zilverentant, J., Boonekamp, P., and Schots, A. 1992. Specificity of polycllonal and monoclonal antibodies for the identification of Xanthomonas campestris pv. campestris. Eur. J. Plant Pathol. 98:81-94.

Greaves, M., and Wilson, M. 1970. The degradation of nucleic acids and montmorillonite-nucleic-acid complexes by soil microorganisms. Soil Biol. Biochem. 2:257-268.

Hardham, A. R., and Blackman, L. M. 2018. Phytophthora cinnamomi. Mol. Plant Pathol. 19:260-285.

Hardy, G. E. St. J., Barrett, S., and Shearer, B. 2001. The future of phosphite as a fungicide to control the soilborne plant pathogen Phytophthora cinnamomi in natural ecosystems. Australas. Plant Pathol. 30:133-139.

Heise, J., Nega, M., Alawi, M., and Wagner, D. 2016. Propidium monoazide treatment to distinguish between live and dead methanogens in pure cultures and environmental samples. J. Microbiol. Methods 121:11-23.

Hudspeth, D. S. S., Nadler, S. A., and Hudspeth, M. E. S. 2000. A COX2 molecular phylogeny of the Peronosporomycetes. Mycologia 92:674-684.

Josephson, K., Gerba, C., and Pepper, I. 1993. Polymerase chain reaction detection of nonviable bacterial pathogens. Appl. Environ. Microbiol. 59:3513-3515.

Jung, T., Orlikowski, L., Henricot, B., Abad-Campos, P., Aday, A., Aguín Casal, O., Bakonyi, J., Cacciola, S., Cech, T., and Chavarriaga, D. 2015. Widespread Phytophthora infestations in European nurseries put forest, semi-natural and horticultural ecosystems at high risk of Phytophthora diseases. For. Pathol. 46:134-163.
Kokoskova, B., and Janse, J. D. 2009. Enzyme-linked immunosorbent assay for the detection and identification of plant pathogenic bacteria (in particular for Erwinia amylovora and Clavibacter michiganensis subsp. sepedonicus). Pages 75-87 in: Plant Pathology: Methods in Molecular Biology. R. Burns, ed. Humana Press, Totowa, NJ.

Kunadiya, M., White, D., Dunstan, W. A., Hardy, G. E. St. J., Andjic, V., and Burgess, T. I. 2017. Pathways to false positive diagnoses using molecular genetic detection methods; Phytophthora cinnamomi a case study. FEMS Microbiol. Lett. 364:fnx009.

Langrell, S. R. H., Morel, O., and Robin, C. 2011. Touchdown nested multiplex PCR detection of Phytophthora cinnamomi and P. cambivora from French and English chestnut grove soils. Fungal Biol. 115:672-682.

Lau, H. Y., and Botella, J. R. 2017. Advanced DNA-based point-of-care diagnostic methods for plant diseases detection. Front. Plant Sci. 8:2016.

Lowe, S., Browne, M., Boudjelas, S., and De Poorter, M. 2000. 100 of the world's worst invasive alien species: A selection from the global invasive species database. http://www.issg.org. IUCN Invasive Species Specialist Group, International Union for Conservation of Nature, Gland, Switzerland.

Malin, E., Roth, D., and Belden, E. 1983. Indirect immunofluorescent staining for detection and identification of Xanthomonas campestris pv. phaseoli in naturally infected bean seed. Plant Dis. 67:645-647.

Martin, F. N., and Tooley, P. W. 2003. Phylogenetic relationships among Phytophthora species inferred from sequence analysis of mitochondrially encoded cytochrome oxidase I and II genes. Mycologia 95:269-284.

Martin, F. N., and Tooley, P. W. 2004. Identification of Phytophthora isolates to species level using restriction fragment length polymorphism analysis of a polymerase chain reaction-amplified region of mitochondrial DNA. Phytopathology 94:983-991

Mendum, T. A., Sockett, R. E., and Hirsch, P. R. 1998. The detection of Gramnegative bacterial mRNA from soil by RT-PCR. FEMS Microbiol. Lett. 164: 369-373.

Miles, T. D., Martin, F. N., and Coffey, M. D. 2014. Development of rapid isothermal amplification assays for detection of Phytophthora spp. in plant tissue. Phytopathology 105:265-278.

Nielsen, K. M., Johnsen, P. J., Bensasson, D., and Daffonchio, D. 2007. Release and persistence of extracellular DNA in the environment. Environ. Biosafety Res. 6:37-53.

Nocker, A., and Camper, A. K. 2006. Selective removal of DNA from dead cells of mixed bacterial communities by use of ethidium monoazide. Appl. Environ. Microbiol. 72:1997-2004

Notomi, T., Okayama, H., Masubuchi, H., Yonekawa, T., Watanabe, K., Amino, N., and Hase, T. 2000. Loop-mediated isothermal amplification of DNA. Nucleic Acids Res. 28:e63.

Nováková, S., Klaudiny, J., Kollerova, E., and Šubr, Z. 2006. Expression of a part of the potato virus A non-structural protein P3 in Escherichia coli for the purpose of antibody preparation and P3 immunodetection in plant material. J. Virol. Methods 137:229-235.

O'Brien, P. A., Williams, N., and Hardy, G. E. St. J. 2009. Detecting Phytophthora. Crit. Rev. Microbiol. 35:169-181.

Paget, E., Monrozier, L. J., and Simonet, P. 1992. Adsorption of DNA on clay minerals: Protection against DNaseI and influence on gene transfer. FEMS Microbiol. Lett. 97:31-39.

Pisz, J. M., Lawrence, J. R., Schafer, A. N., and Siciliano, S. D. 2007 Differentiation of genes extracted from non-viable versus viable microorganisms in environmental samples using ethidium monoazide bromide. J. Microbiol. Methods 71:312-318.

Recorbet, G., Picard, C., Normand, P., and Simonet, P. 1993. Kinetics of the persistence of chromosomal DNA from genetically engineered Escherichia coli introduced into soil. Appl. Environ. Microbiol. 59:4289-4294.

Rittershaus, E. S., Baek, S.-H., and Sassetti, C. M. 2013. The normalcy of dormancy: Common themes in microbial quiescence. Cell Host Microbe 13 643-651.

Romanowski, G., Lorenz, M., and Wackernagel, W. 1993. Use of polymerase chain reaction and electroporation of Escherichia coli to monitor the persistence of extracellular plasmid DNA introduced into natural soils. Appl Environ. Microbiol. 59:3438-3446.

Romanowski, G., Lorenz, M. G., Sayler, G., and Wackernagel, W. 1992. Persistence of free plasmid DNA in soil monitored by various methods, including a transformation assay. Appl. Environ. Microbiol. 58:3012-3019.

Sakalidis, M. L., Hardy, G. E. S., and Burgess, T. I. 2011. Endophytes as potential pathogens of the baobab species Adansonia gregorii: A focus on the Botryosphaeriaceae. Fungal Ecol. 4:1-14.

Schena, L., Duncan, J. M., and Cooke, D. E. L. 2008. Development and application of a PCR-based 'molecular tool box' for the identification of Phytophthora species damaging forests and natural ecosystems. Plant Pathol. 57:64-75.

Scheu, P. M., Berghof, K., and Stahl, U. 1998. Detection of pathogenic and spoilage micro-organisms in food with the polymerase chain reaction. Food Microbiol. 15:13-31.

Sena, K., Dreaden, T. J., Crocker, E., and Barton, C. 2018. Detection of Phytophthora cinnamomi in forest soils by PCR on DNA extracted from leaf disc baits. Plant Health Prog. 19:193-200.

Shearer, B., Crane, C., Barrett, S., and Cochrane, A. 2007. Phytophthora cinnamomi invasion, a major threatening process to conservation of flora 
diversity in the South-west Botanical Province of Western Australia. Aust. J. Bot. 55:225-238.

Shearer, B. L., Crane, C. E., and Fairman, R. G. 2004. Phosphite reduces disease extension of a Phytophthora cinnamomi front in Banksia woodland, even after fire.. Australas. Plant Pathol. 33:249-254.

Shearer, B. L., and Tippett, J. T. 1989. Jarrah dieback: The dynamics and management of Phytophthora cinnamomi in the jarrah (Eucalyptus marginata) forest of south western Australia. Research Bulletin No. 3. Department of Conservation and Land Management, Como, Western Australia.

Sheridan, G., Masters, C., Shallcross, J., and Mackey, B. 1998. Detection of mRNA by reverse transcription-PCR as an indicator of viability in Escherichia coli cells. Appl. Environ. Microbiol. 64:1313-1318.

Simamora, A., Paap, T., Howard, K., Stukely, M. J. C., Hardy, G. E. S., and Burgess, T. I. 2018. Phytophthora contamination in a nursery and its potential dispersal into the natural environment. Plant Dis. 102:132-139.

Taylor, J. W., Jacobson, D. J., Kroken, S., Kasuga, T., Geiser, D. M., Hibbett, D. S., and Fisher, M. C. 2000. Phylogenetic species recognition and species concepts in fungi. Fungal Genet. Biol. 31:21-32.

Tomlinson, J., Dickinson, M., and Boonham, N. 2010. Rapid detection of Phytophthora ramorum and $P$. kernoviae by two-minute DNA extraction followed by isothermal amplification and amplicon detection by generic lateral flow device. Phytopathology 100:143-149.

Tsao, P. H., and Ocana, G. 1969. Selective isolation of species of Phytophthora from natural soils on an improved antibiotic medium. Nature 223:636-638.
Varma, M., Field, R., Stinson, M., Rukovets, B., Wymer, L., and Haugland, R. 2009. Quantitative real-time PCR analysis of total and propidium monoazide-resistant fecal indicator bacteria in wastewater. Water Res. 43:4790-4801.

Vettraino, A., Sukno, S., Vannini, A., and Garbelotto, M. 2010. Diagnostic sensitivity and specificity of different methods used by two laboratories for the detection of Phytophthora ramorum on multiple natural hosts. Plant Pathol. 59:289-300.

Vincent, M., Xu, Y., and Kong, H. 2004. Helicase-dependent isothermal DNA amplification. EMBO Rep. 5:795-800.

Wagner, A. O., Malin, C., Knapp, B. A., and Illmer, P. 2008. Removal of free extracellular DNA from environmental samples by ethidium monoazide and propidium monoazide. Appl. Environ. Microbiol. 74:2537-2539.

Weste, G. 2003. The dieback cycle in Victorian forests: A 30-year study of changes caused by Phytophthora cinnamomi in Victorian open forests, woodlands and heathlands. Australas. Plant Pathol. 32:247-256.

Widmer, F., Seidler, R., and Watrud, L. 1996. Sensitive detection of transgenic plant marker gene persistence in soil microcosms. Mol. Ecol. 5:603-613.

Wilson, B. A., and Laidlaw, W. S. 2001. Impact of Phytophthora cinnamomi on mammals in southern Australia. in: Proceedings of 2nd International IUFRO Meeting, Albany, Western Australia.

Zentmyer, G. A. 1983. The world of Phytophthora. Pages 1-7 in: Phytophthora: Its Biology, Taxonomy, Ecology, and Pathology. D. C. Erwin, S. Bartnicki-Garcia, and P. H. Tsao, eds. American Phytopathological Society, St. Paul, MN. 